\title{
Measuring Quality Performance of Anti-Drugs Units by Using Six - Sigma
}

\author{
Dr. Abdalla Ahmed Alkhalifa ${ }^{1}$, Dr. Ehab Ahmed Mohammed ${ }^{2}$ \\ ${ }^{1,2}$ University of Tabuk "KSA"- Faculty of Science, Department of Statistics \\ Thanks for the Deanship of Scientific Research (DSR), University of Tabuk for financial support for this work "research No. 0210/1436
}

\begin{abstract}
Drugs abuse is one of the most disastrous social and health phenomena that the present day society faces. The world has been afflicted with drugs addiction, which represents a threat to security and stability as well as it causes loss of human souls. The world has become a global village and this resulted in shared customs and behaviors, and with that, the phenomenon of drugs use has spread. Each society or part of society is inseparable from the rest of the world, interacts with, and is affected by it. Accordingly, no human society is spared the spread of this devastating phenomenon. The society, then, has to play its role in preventing and fighting the risk and danger of addiction and that its dreadful influence should be explained to youth, family, and heath and intellectual orientation campaigns for the different segments of the society should be held. Every available facility should be utilized to fight this dangerous trend, whether it is visual, audio or printed media or through making legislations that prohibit and punish it and adopting very strict measures against its spread. The society sectors should work collaboratively and coordinate with the other countries as for security issues benefiting from each other's experiences in fighting and controlling drugs. The reasons for drugs use are different from one country to another and from one society to another within the same country. Among the major reasons are weak personality, weak religious deterrent and the easy accessibility of drugs, the influence of friends and peers, lack of entertainment facilities, use of drugs for health purposes, for sexual bliss, family troubles, blind imitation to others and the spread of unemployment. The use of drugs especially among youths has several threats. It is like throwing a stone at a stagnant pond where the circle enlarges. In the beginning the danger of drugs use is restricted to the user but gradually it includes the family, friends, school, the youth gatherings and eventually the whole society. The negative effects of drugs on the personal level is physical and psychological and on the society level, we find security, economical and religious, and political as well as political violations.
\end{abstract}

Keywords: anti-drugs, six-sigma

\section{Global Drugs Statistics}

A report from the United Nations Office on Drugs and Crime (UNODC) has revealed that 230 million individuals have used prohibited drugs at least once in their lives and number $\mathrm{o}$ addicts around the world amounts to 27 million. I.e. 1 in each 200 in the world. The (UNODC) indicates that this number will increase to 300 in the year 2100 . According to the report, the ratio of drugs consumption has been constant for many years especially in the industrial countries of Europe and North America. The land cultivated with opium is estimated to two thousand square kilometers, an area equal to the area of Zalando in the north west of Germany. The report has also pointed to an increase in the number of drugs consumers in the developing countries. Among these countries is China, in which heroin consumers are estimated to be one million as disclosed by the Chinese government, whereas the (UNODC) estimates heroin use in china to be about 4.2 million. The use of heroin and cocaine is not restricted to privileged cities like Berlin and New York. It is found in Western and Central Africa. Afghanistan and Pakistan are no longer only producers of drugs. Thousands of their citizens are heroin addicts. The report has also reflected that many of drugs inhalers or those who take it orally tend to use addiction- causing synthetic drugs. In America, there is noticeable increase in synthetic drugs. ( Vido Tof) the prominent drugs control pioneer mentions Michael Jackson as an example in a report to the German News agency. Vido TOf emphasizes that the death rates caused by the use of synthetic drugs are more than that caused by the use of cocaine and heroin collaboratively. The deaths caused by these drugs amounted to 12 thousands annually compared to 6 thousands deaths of cocaine and heroin use. Beside the
Hash and cannabis, heroin and cocaine, synthetic drugs that lead to quick excitement has flourished. Men tend to use strong drugs while women are more likely to use sedative bills instead of drugs. However, the sedative pills also lead to addiction. Vido also points to the types of permissible addiction risks. According to him, 200 million die of the use of prohibited drugs whereas, 2.3 million die of alcohol, and 5.1 die of smoking. In spite of all these facts, the organization avoided discussing the possibility of legalizing strong drugs in response to the demands of many people in the western societies on the ground that allowing drugs will hinder the flow of money to drugs mafias in the world. Thomas Betchman, the drugs statistics expert in the International Organization claims that if not prohibited, the use of drugs and the number of addicts will increase significantly, stressing that there are no signs of any decrease in the use of drugs or any victory against its gangs through the traditional methods used thus far.

\section{The Six -Stigma Concept}

The Six-Stigma standard is considered one of the most important concepts in the fields of comprehensive quality control. This concept emerged in Motorola Company in the beginning of the eighties of the previous century. It spread vastly and the biggest world companies adopted and applied it to their different administrative procedures. The idea of Six- Stigma lies in that if the institution is able to measure the inadequacy in some process, it will be able to fix it and eventually come near the stage of free of defect. it includes a method and an administrative philosophy based on a strict principle that seeks to concentrate all efforts to obtain high quality products and services, with the least cost and in the fastest time. 


\section{International Journal of Science and Research (IJSR) \\ ISSN (Online): 2319-7064}

Index Copernicus Value (2013): 6.14 | Impact Factor (2014): 5.611

\section{Definition of Six - Sigma}

The stigma-six is defined as a program for quality improvement that seeks to limit the number of inadequacies in the production process to be 3.4 in each million chances and it is also defined as a method for improving a product which is free of inadequacy. It is also defined as a method or philosophy used to eliminate or limit inadequacies in the processes and outputs of the organization. All literature reviews agree on the definition of Six Stigma in three ways

\subsection{Six-Sigma as a statistical measure}

When a company plans to produce a good, it considers the needs and expectations of the consumers and tries to specify the characteristics that are indispensable to quality ( the specifications that are central to the consumer) as well as the cost. Any divergence in the product from the expectation of the consumer will negatively influence the consumer's trust in the product and consequently in the company. Therefore, the designers usually consider the best design at the lowest cost. The consumer allows divergence from the pre-defined specifications within limits. The arithmetic mean for critical specifications in the products is worked out and checked against quality specifications and the company measures and controls the outputs in a way to guarantee the acceptable range. Among the widely spread measures for measuring divergence is the standard deviation symbolized by Sigma ( $\sigma$ ) borrowed from the
Roman Language. It is a statistical method for measuring the level of the product deviation from the pre-defined specifications as the standard deviation shows the dispersion of the data from the arithmetic mean, and the standard deviation takes the following form:

$$
\sigma=\sqrt{\frac{\sum_{i=1}^{N}\left(X_{i}-\mu\right)^{2}}{N}}
$$

Where: $\sigma$ is the population standard deviation, $x_{i}$ is the values of the variable and $\mathrm{u}$ is the population mean "in case of sample the sample statistics replace the population parameters with numerator $n-1$. If the value of the standard deviation is little, this shows that observations of the product are spread around the arithmetic mean, and if it is equal to zero, it means that observations of the product are equal to the arithmetic mean. If the company is keen on making the specifications of the product correspond to the pre-defined specifications, this requires that the products should be monitored to prevent any divergence of any type in the product within the acceptable limits $(u \pm \sigma)$. The data dispersed around the mean takes the normal distribution with a mean u and variance $\sigma^{2}$, the normal probability density function is:

$$
f(x)=\frac{1}{\sqrt{2 \pi \sigma^{2}}} e^{-\frac{1}{2}\left(\frac{x-\mu}{\sigma}\right)^{2}}-\infty \leq x \leq \infty
$$

The curve in figure (1) shows the standard normal curve $\left[\mathrm{z}^{\sim}\right.$ $\mathrm{N}(0,1)]$ :

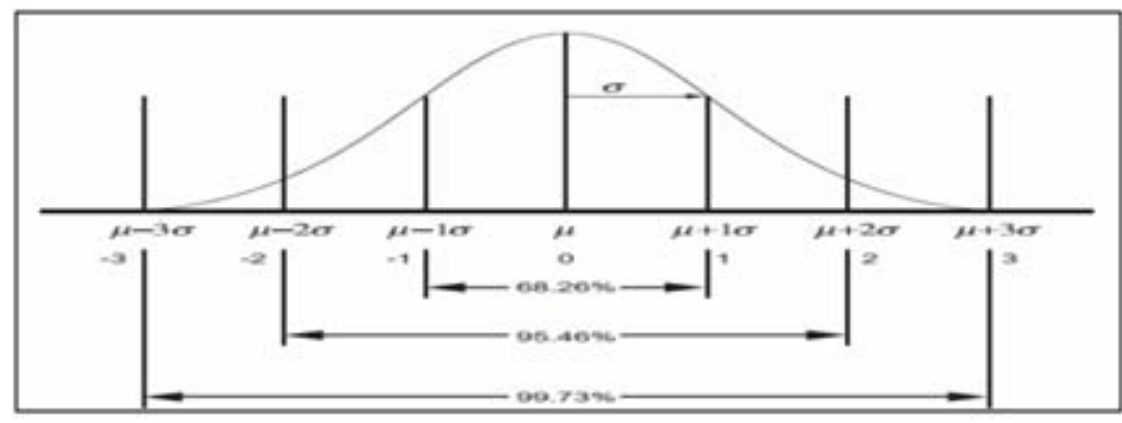

Figure 1: Standard normal curve

Source: Joglekar (2013)

Figure 1 shows that $68.26 \%$ of the area under curve lies between $\mu \mp \sigma$ i.e. about $68.26 \%$ of services and products have good standards. In addition, $32.74 \%$ lies out of $\mu \mp \sigma$. which means it is out of standards. And so for $95.46 \%$ lies between $\mu \mp 2 \sigma$ and $99.73 \%$ lies between $\mp 3 \sigma$. The following table shows the different levels of $\sigma$ :

Table 1: levels of $\sigma$ and number of defects for each level

\begin{tabular}{|c|c|}
\hline Level of $\sigma$ & Defects per million opportunity \\
\hline & 3.4 \\
\hline & 233 \\
\hline & 6210 \\
\hline & 66807 \\
\hline & 308537 \\
\hline & 690000 \\
\hline
\end{tabular}

Source: www.isixsigma.com
Indicating that Six Sigma is statistical tool which measure dispersion of data around mean or group of data -less dispersion less defects in service or product, also it's the operation which yields 3.4 defects in each million opportunity. 
International Journal of Science and Research (IJSR)

ISSN (Online): 2319-7064

Index Copernicus Value (2013): 6.14 | Impact Factor (2014): 5.611

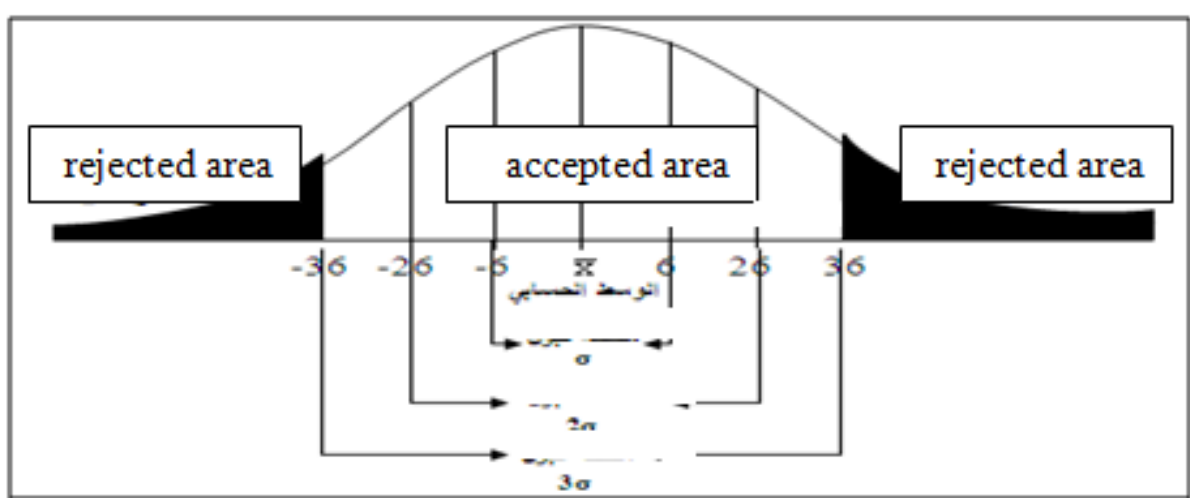

Figure 2: Accepted area and rejected area

Source: Elniemi Mohammed (2007)

Figure 2 shows the acceptance limits for three sigma and the shaded area is the rejection area. This is the most applied in statistical studies with percentages $0.1,0.05$, 0.01 , and 0.01 is the best for optimal accepting or rejecting i.e. with standards level 0.99 and it is good ,but last development needs to increase quality.

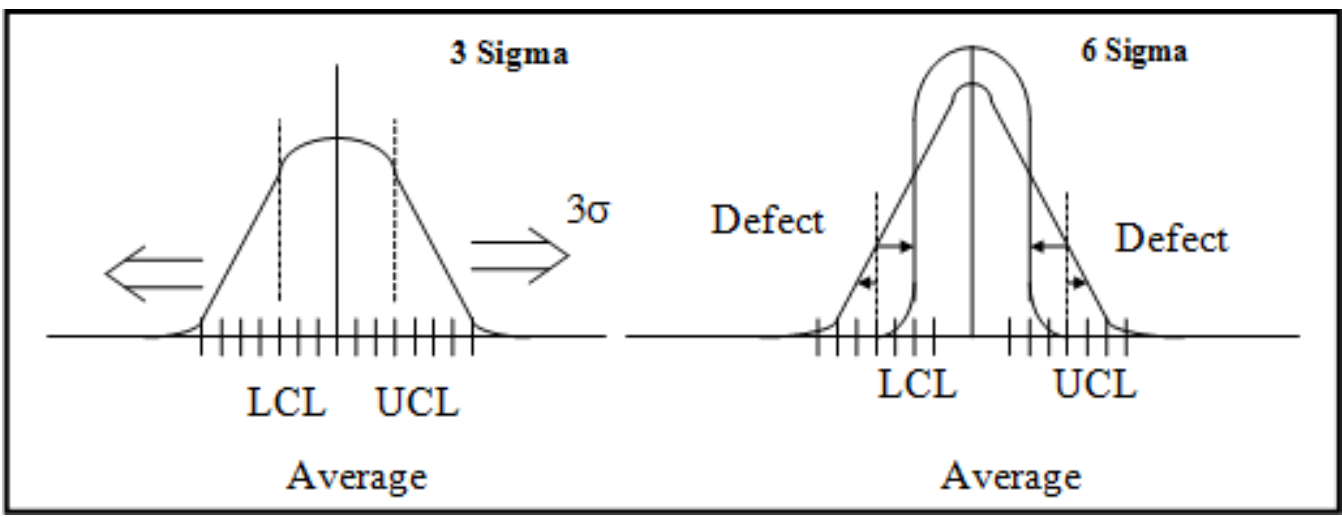

Figure 3: Comparison between Six Sigma and Three Sigma for reducing variability

Source: Wary, Bruce \& Hogan, Bob.)2002(

Six sigma as an objective

The three objectives for six sigma are Increase customer satisfaction, Reduce the time-required cycle and Reduce defects.

\section{Six sigma as an administration system}

Six sigma represent an administration system, which provides mangers with analytical methods and tools to solve problems. In addition, it seeks to achieve non-defects stage So as to satisfy customer by good product and low cost.

\subsection{Strategies of applying six sigma (DMAIC} methodology)

\section{Primary Step of Planning}

Include four steps

\section{a) Introduction}

The training of senior management and cadres to understand the importance of six sigma, so they can support application of it.

\section{b) Experimentation Step:}

The trained team starts to apply small selected projects under the supervision of experts.

\section{c) Application Step}

Evaluate step two and develop it carefully to be as a base for six sigma programs.

\section{d) Contineuinty}

Continuing in applications until it be as culture in the organization.

\section{Six Sigma Application step:}

It begins with the application of Six Sigma identifying the problem and then select the appropriate form to alleviate or drying problem. A working group called Team Six Sigma adopts this program, and there are multiple models lead to improved performance, including:

\section{- DMAIC • DMADV}

The approach DMAIC is more used when applying Six Sigma, and is used when the organization in need to the development of the services or products.

DMAIC is an abbreviation for Definition, Measurement, Analysis, Improvement and Control. where DMADVis definition, measurement, analysis, design and evaluation, We will discuss the methodology DMAIC because they are the most commonly used 


\section{International Journal of Science and Research (IJSR) \\ ISSN (Online): 2319-7064 \\ Index Copernicus Value (2013): 6.14 | Impact Factor (2014): 5.611}

a) Definition phase: Defining the problem and its causes.

b) Measurement phase: Include collecting data to understand the problem and hence determine the best measure to be used.

\section{Analysis Phase}

Defining the defects and determine the statistical methods which enables to analyze causes of the problem.

\section{Improvement Phase}

Includes all activities that contribute to the process of improving the performance and increase the level of service through:

1) How to get rid of defects and negatives

2) Explore different solutions to the problem

3) Choose the suitable solution and measuring result

\section{Control Phase}

Follow-up operations and make sure not to repeat the mistakes while continuing the development of work and give information to senior management project outputs.

\subsection{Concepts of Six Sigma}

1) Unit: it is a product or service or level of service under study.

2) Defective unit: units not matching standards or customer requirements.

3) Defects per Unit (DPU):

$$
\text { DPU }=\frac{\text { Numberofdefects }}{\text { numberofunits }}
$$

4) Defect Opportunity: number of probable opportunities that may be defective in unit, there may be many defective opportunities in one unit.

5) Defect per Opportunity (DPO):

$$
\mathrm{DPO}=\frac{\mathrm{DPU}}{\text { numberofopportunities }}
$$

6) Defects per Million Opportunity (DPMO)

7) Yield free of defectives "Y": units satisfying standards are those free of defects.

8) Rolled Throughput Yield (RTY): represents product which is free of defects for all partial operations.

such that:

$$
: \mathrm{RTY}=\mathrm{Y}_{1} \quad 2 \quad \cdots \quad \mathrm{k}=\prod_{\mathrm{i}=1}^{\mathrm{k}} \mathrm{Y}_{\mathrm{i}}
$$

$\mathrm{Y}_{\mathrm{i}} \equiv$ Yield free of defects in step i

$\mathrm{k} \equiv$ number of steps in production or service

level of sigma-:

Then the value obtained used to determine the level of sigma under which the organization work as in table 2.

Table 2: Sigma Levels and DPMO

\begin{tabular}{|c|c|c|}
\hline Process yield\% & DPMO & Sigma Level \\
\hline 30.85 & 691.500 & 1 \\
\hline 69.15 & 308.500 & 2 \\
\hline 93.32 & 66.800 & 3 \\
\hline 99.38 & 6.200 & 4 \\
\hline 99.977 & 230 & 5 \\
\hline 99.99966 & 3.4 & 6 \\
\hline
\end{tabular}

source: Joglekar (2003)

\subsection{The Application Side}

This research focused on measuring the performance of fighting the crimes of Drugs smuggling from abroad into the country and possession of drugs. First, measure the monthly quality performance during the year for the two crimes together, and the quality of performance for each crime separately during the months of the year, then the quality of the overall performance during the year for each crime separately and then the two together.

State name is assumed as $\mathrm{X}$ and hypothetical sample was chosen - to apply the confidentiality of the data in this area consisting of 907 crimes committegd in one year whereas the number of the crimes which were not averted has reached 309

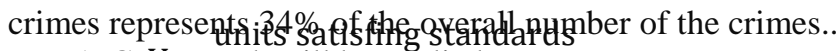

\begin{tabular}{|c|c|c|}
\hline Stage & Aim & Description \\
\hline Definition & $\begin{array}{l}\text { Identification of the } \\
\text { problem (Defects). }\end{array}$ & Not being able to avert about $34 \%$ of the crimes before they occur in the state (X). \\
\hline $\begin{array}{l}\text { Measurement } \\
\text { stage }\end{array}$ & $\begin{array}{l}\text { Identification of the critical } \\
\text { characteristics of quality. }\end{array}$ & $\begin{array}{l}\text { Identify the factors that guide to hinder the prevention of these crimes at the } \\
\text { specified time ( survey method or interviews can be used to measure the impact of } \\
\text { these factors) or take advantage of the studies that have been performed in this area. }\end{array}$ \\
\hline $\begin{array}{l}\text { Analysis } \\
\text { Stage }\end{array}$ & $\begin{array}{l}\text { Deep comprehension of the } \\
\text { causes of the defects (the } \\
\text { problem) }\end{array}$ & $\begin{array}{l}\text { Deep understanding of the variables of direct and indirect factors that hinder } \\
\text { preventing crimes at the appropriate time. This may provide an early indication to the } \\
\text { Anti- Drugs Administration to avoid these factors. }\end{array}$ \\
\hline $\begin{array}{l}\text { Optimization } \\
\text { stage }\end{array}$ & $\begin{array}{l}\text { Determine the number of } \\
\text { key variables and their } \\
\text { impact on the critical } \\
\text { characteristics of quality. }\end{array}$ & $\begin{array}{c}\text { Determine acceptable strategies to reduce the number of crimes that have not been } \\
\text { averted at the suitable time (This step may require the use of multiple statistical } \\
\text { methods and tools to identify high-impact variables in the problem). Define } \\
\text { acceptable strategies to reduce or scrub out the impact of the factors that hinder } \\
\text { averting crimes at the appropriate time, which consequently leads to improved } \\
\text { performance in the control( fighting) operations. }\end{array}$ \\
\hline Control stage & $\begin{array}{l}\text { To ensure that the } \\
\text { modifications within the } \\
\text { framework of an acceptable } \\
\text { system. }\end{array}$ & $\begin{array}{l}\text { To ensure that the proposed strategies to solve the problem of the inability to prevent } \\
\text { crimes on time, occur within an acceptable and systematic framework and } \\
\text { continuous supervision process }\end{array}$ \\
\hline
\end{tabular}
DMAIC approach will to applied.

Table 3: Application of DMAIC approach on the anti- narcotic operations in the state (X)

Source: Researcher's Preparation. 


\section{International Journal of Science and Research (IJSR) \\ ISSN (Online): 2319-7064 \\ Index Copernicus Value (2013): 6.14 | Impact Factor (2014): 5.611}

To calculate the value of sigma six for the previous case, the researcher made the followings:

Terms have been defined according to the concepts of sigma six as follows:

a. If the criminal operation was not aborted on time (the crime was discovered after a period) the unit is considered as "defective".

Table 4: total drugs crimes in the country / month

\begin{tabular}{|c|c|c|c|c|c|c|}
\hline $\begin{array}{l}\text { The period of } \\
\text { time }\end{array}$ & $\begin{array}{l}\text { Number of drugs } \\
\text { smuggling crimes } \\
\text { inside the country }\end{array}$ & $\begin{array}{l}\text { number of drugs } \\
\text { smuggling crimes, } \\
\text { which were not } \\
\text { averted on time }\end{array}$ & $\begin{array}{l}\text { Number of } \\
\text { drugs } \\
\text { possession } \\
\text { crimes }\end{array}$ & $\begin{array}{l}\text { Number of drugs } \\
\text { possession crimes } \\
\text { which were not } \\
\text { discovered on time. }\end{array}$ & $\begin{array}{l}\text { total } \\
\text { number } \\
\text { of } \\
\text { crimes }\end{array}$ & $\begin{array}{l}\text { total number of } \\
\text { crimes that were } \\
\text { not averted on the } \\
\text { appropriate time. }\end{array}$ \\
\hline January & 9 & 2 & 60 & 18 & 69 & 20 \\
\hline February & 10 & 3 & 65 & 19 & 75 & 22 \\
\hline March & 8 & 3 & 73 & 21 & 81 & 24 \\
\hline April & 7 & 2 & 70 & 16 & 77 & 18 \\
\hline May & 6 & 2 & 61 & 21 & 67 & 23 \\
\hline June & 11 & 7 & 74 & 28 & 85 & 35 \\
\hline July & 12 & 8 & 78 & 33 & 90 & 41 \\
\hline August & 9 & 5 & 78 & 33 & 87 & 38 \\
\hline September & 7 & 3 & 71 & 19 & 78 & 22 \\
\hline October & 5 & 2 & 65 & 21 & 70 & 23 \\
\hline November & 6 & 3 & 59 & 16 & 65 & 19 \\
\hline December & 7 & 4 & 56 & 20 & 63 & 24 \\
\hline The mean & 8 & 4 & 68 & 22 & 76 & 26 \\
\hline
\end{tabular}

Source: researcher's preparation

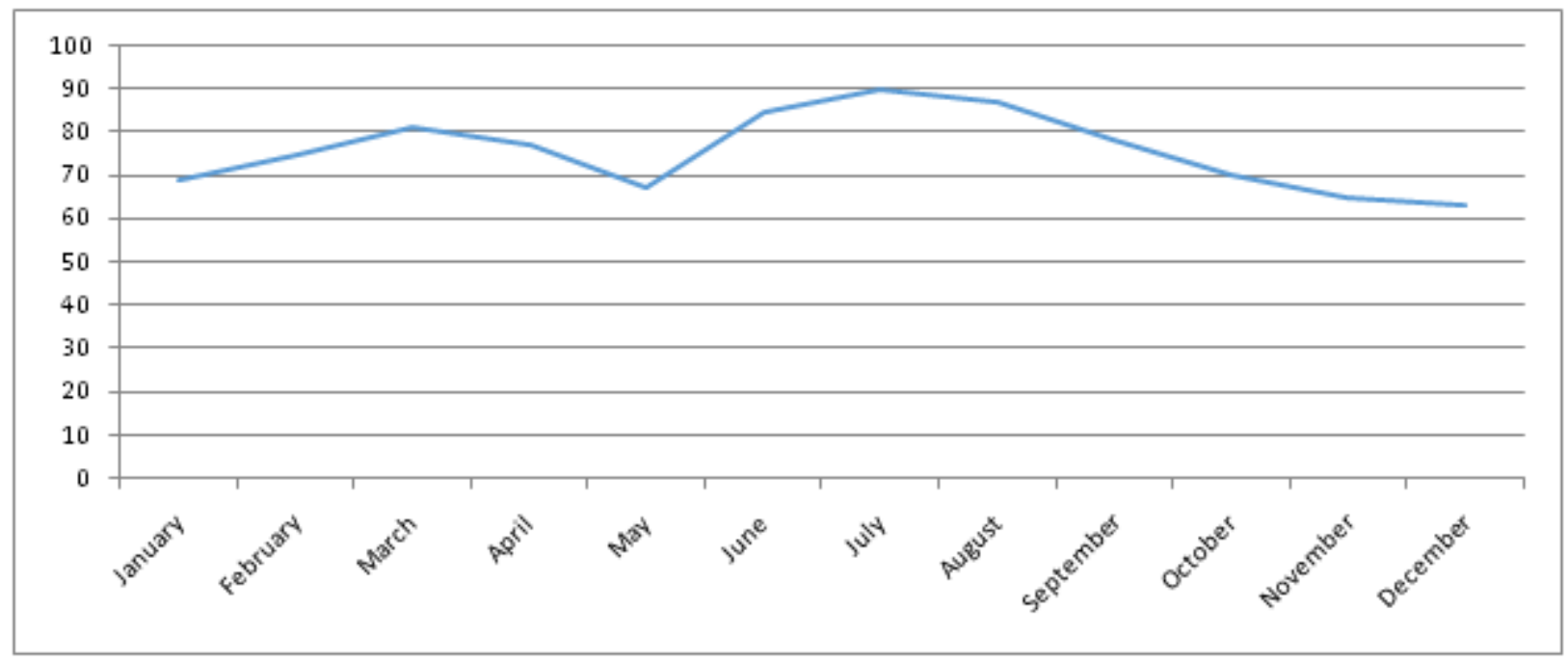

Figure 4: Shows the general trend of Drugs crimes in the state $X$

Source: researcher's preparation

From Figure (4) it is clear that there is apparent rise in the number of crimes in the months of June, August and September, which represents the summer months. This rise 3.6 Measuring the quality of performance in general: can be due to the vacation during these months which makes the Drugs trade active more than other months. b. The number of crimes which were not averted on time, divided by the total number of the crimes, is considered as percentage for defects in one unit and the defects in one unit represent a percentage for the lack of segmentation for the defective unit. 


\section{International Journal of Science and Research (IJSR) \\ ISSN (Online): 2319-7064}

Index Copernicus Value (2013): 6.14 | Impact Factor (2014): 5.611

Table 5: Sigma level for total drugs crimes / month

\begin{tabular}{|c|c|c|c|c|c|}
\hline $\begin{array}{c}\text { The period } \\
\text { of time }\end{array}$ & $\begin{array}{c}\text { The total number } \\
\text { of the crimes }\end{array}$ & $\begin{array}{c}\text { The number of drugs smuggling crimes, } \\
\text { which were not averted on time }\end{array}$ & $\begin{array}{c}\text { Defects in one } \\
\text { opportunity }\end{array}$ & $\begin{array}{c}\text { Defects in million } \\
\text { opportunities }\end{array}$ & $\begin{array}{c}\text { Level of } \\
\text { sigma }\end{array}$ \\
\hline January & 69 & 20 & 0.29 & 289855 & 2.04 \\
\hline February & 75 & 22 & 0.29 & 293333 & 2.25 \\
\hline March & 81 & 24 & 0.30 & 296296 & 2.01 \\
\hline April & 77 & 18 & 0.23 & 233766 & 2.22 \\
\hline May & 67 & 23 & 0.34 & 343284 & 1.87 \\
\hline June & 85 & 35 & 0.41 & 411765 & 1.65 \\
\hline July & 90 & 41 & 0.46 & 455556 & 1.5 \\
\hline August & 87 & 38 & 0.44 & 436781 & 1.57 \\
\hline September & 78 & 22 & 0.28 & 282051 & 2.06 \\
\hline October & 70 & 23 & 0.32 & 328571 & 1.92 \\
\hline November & 65 & 19 & 0.29 & 292308 & 2.03 \\
\hline December & 63 & 24 & 0.38 & 375000 & 1.77 \\
\hline
\end{tabular}

Source: researcher's preparation

\subsection{Measuring the quality of performance for the crime of drugs smuggling from abroad:}

Table 6: Sigma level for monthly drugs smuggling crimes form abroad:

\begin{tabular}{|c|c|c|c|c|c|}
\hline time /month & $\begin{array}{c}\text { Total Number of } \\
\text { smuggling crimes }\end{array}$ & $\begin{array}{c}\text { Number of smuggling crimes } \\
\text { which were not averted on time }\end{array}$ & $\begin{array}{c}\text { Defects per } \\
\text { opportunity }\end{array}$ & $\begin{array}{c}\text { Defects in a } \\
\text { million chance }\end{array}$ & sigma \\
\hline January & 9 & 2 & 0.22 & 222222 & 2.3 \\
\hline February & 10 & 3 & 0.30 & 300000 & 2.0 \\
\hline March & 8 & 3 & 0.38 & 375000 & 1.8 \\
\hline April & 7 & 2 & 0.29 & 285714 & 2.1 \\
\hline May & 6 & 2 & 0.33 & 333333 & 1.9 \\
\hline June & 11 & 7 & 0.64 & 636364 & 1.0 \\
\hline July & 12 & 8 & 0.66 & 666667 & 1.0 \\
\hline August & 9 & 5 & 0.56 & 555556 & 1.0 \\
\hline September & 7 & 3 & 0.43 & 428571 & 2.2 \\
\hline October & 5 & 2 & 0.40 & 400000 & 1.7 \\
\hline November & 6 & 3 & 0.50 & 500000 & 1.3 \\
\hline December & 7 & 4 & 0.57 & 571429 & 1.0 \\
\hline
\end{tabular}

Source: researcher's preparation

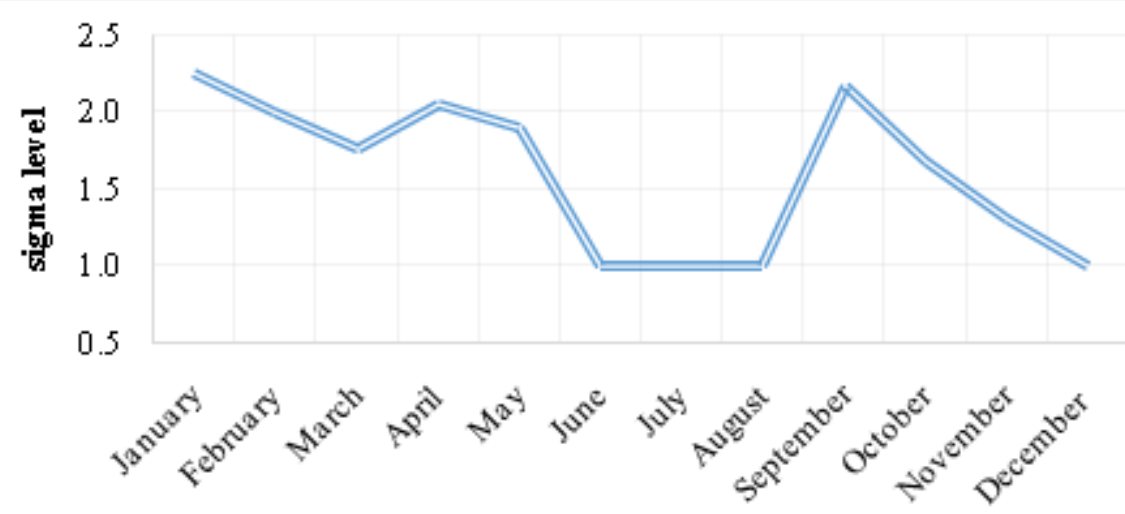

Figure 6: Show the monthly sigma level of drugs smuggling from abroad in country X:

Source: researcher's preparation

Table (6) and Fig. (6) represent a higher level of performance to fighting the crime of drugs trafficking was in January and the lowest level of performance was in the months of June, July, August and December, generally, the performance during the winter months is best than performance during the summer months in which the performance is very low with level of Sigma $=1$.
3.8 Measuring the performance quality for drugs possession crime 


\section{International Journal of Science and Research (IJSR) \\ ISSN (Online): 2319-7064}

Index Copernicus Value (2013): 6.14 | Impact Factor (2014): 5.611

Table 7: Show the monthly sigma level of drugs possession crime:

\begin{tabular}{|c|c|c|c|c|c|}
\hline Time /Month & $\begin{array}{c}\text { Total Number of drugs } \\
\text { possession crimes }\end{array}$ & $\begin{array}{c}\text { Number of drugs possession crimes } \\
\text { which were not averted on time }\end{array}$ & $\begin{array}{c}\text { Defects per } \\
\text { opportunity }\end{array}$ & $\begin{array}{c}\text { Defects in a } \\
\text { million chance }\end{array}$ & sigma \\
\hline January & 60 & 18 & 0.30 & 300000 & 2 \\
\hline February & 65 & 19 & 0.29 & 292331 & 2.03 \\
\hline March & 73 & 21 & 0.29 & 287671 & 2.05 \\
\hline April & 70 & 16 & 0.23 & 228571 & 2.24 \\
\hline May & 61 & 21 & 0.34 & 344262 & 1.87 \\
\hline June & 74 & 28 & 0.38 & 378378 & 1.76 \\
\hline July & 78 & 33 & 0.42 & 423077 & 1.61 \\
\hline August & 78 & 33 & 0.42 & 423077 & 1.61 \\
\hline September & 71 & 19 & 0.27 & 267606 & 2.11 \\
\hline October & 65 & 21 & 0.32 & 323077 & 1.93 \\
\hline November & 59 & 16 & 0.27 & 271186 & 2.1 \\
\hline December & 56 & 20 & 0.36 & 357143 & 1.83 \\
\hline Soure
\end{tabular}

Source: researcher's preparation

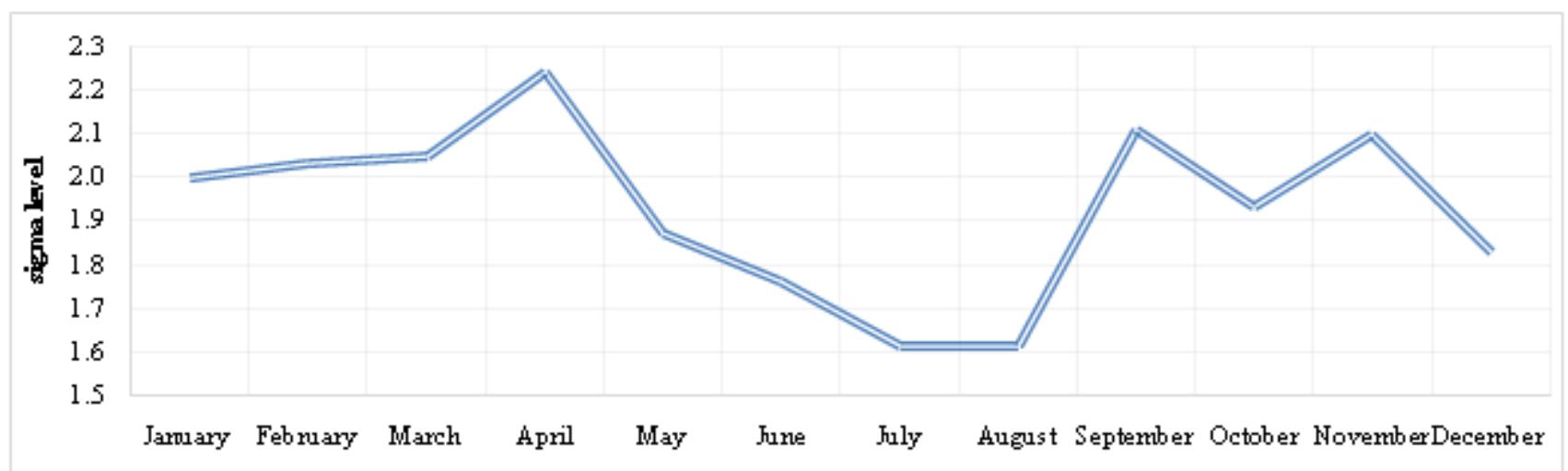

Source: researcher's preparation

Figure 7: Show the monthly sigma level of drugs possession crime in country X :

Table(7) and fig.(7) show that the highest performance level for fighting drugs possession crimes was in the month of April and the lowest level was in July and August, so the performance during the winter months is best than the performance during the summer months.
3.9 Measuring the performance for the total of the two crimes all over the year:

Table 8: Sigma level of performance the total of the two crimes all over the year

\begin{tabular}{|c|c|c|c|c|c|}
\hline Crime & $\begin{array}{c}\text { Crime } \\
\text { average }\end{array}$ & $\begin{array}{c}\text { Average of drugs possession crimes } \\
\text { which were not averted on time }\end{array}$ & $\begin{array}{c}\text { Defects per } \\
\text { opportunity }\end{array}$ & $\begin{array}{c}\text { Defects in a } \\
\text { million chance }\end{array}$ & sigma \\
\hline $\begin{array}{c}\text { Drugs smuggling } \\
\text { from abroad }\end{array}$ & 8 & 4 & 0.5 & 500000 & 1.31 \\
\hline drugs possession & 68 & 22 & 0.32 & 323529 & 1.93 \\
\hline Total & 76 & 26 & 0.34 & 342105 & 1.87 \\
\hline
\end{tabular}

Source: researcher's preparation

Table ( 8) Shows that the he level of performance for fighting drugs possession crimes is better than the performance level for fighting drugs smuggling. And the overall performance for fighting of drugs is weak in country X.

\section{Results}

1) The level of the overall performance in the country is very weak, since the Sigma level is equal to 1.87 , which means that about 308,500 crimes out of million crimes were not averted on time.

2) The level of performance for the combat of crime of drugs possession is better than that of smuggling crimes.
3) Performance in winter is better than in summer.

4) There is not a sound performance in any month during the year.

\section{Recommendations}

1) Improve the working environment and its tools in antidrugs units in the country .

2) Pay more Attention in summer season which noted the high number of crimes and the weakness of control during this season.

3) Application of six sigma measure periodically, to see change in the performance and then assess the efforts done for improvement. 


\section{References}

[1] El Nuaimi, Mohamed Abdel Aal (2009), "Six Sigma as Advanced statistical method to reach the lowest possible error ratio," Paper presented to the Second Conference of the Arab statistical

[2] Joglekar,AnandM,"Statistical Methods for Six Sigma", (John Wiley \& Sons, Inc., Hoboken, New Jersey.USA, 2003).

[3] Ibn Said, Khaled Saad Abdulaziz, "six sigma applications on enterprise of services and industries," Riyadh 2004).

[4] Pande, P., Neuman, R. and Cavanagh, R,"The Six Sigma Way: How GE, Motorola and Other Top Companies are Horning their Performance",(New York: McGraw-Hill, 2000)

[5] Pande, P. and Holpp, L,"What is Six Sigma?",(McGraw-Hill Companies, U.S.A.2002),

[6] PAUL ,L.E., "Practice Make Perfect ", (CIO Enterprise , Vol. 12 ,No 7, Section 2 ,1999)PP. 2 - 25.

[7] Saffawi, saffa Muzahim and Mohammed Yahya (2009), "Statistical analysis using the method of" six sigma, Paper presented to the Second Arab Statistical Conference.

[8] Shamans, Amal salama, "the application of Six Sigma in the educational field," King Saud University Journal of Educational Sciences and Islamic Studies, Issue 18, 2005, p. S89-136.

[9] Stephens, K., "Six Sigma And Related Studies in the Quality Disciplines". (Milwaukee: Quality Press.2003).

[10] Wary, Bruce \& Hogan, Bob., " Why Six Sigma in A Securities Operation", (Bank of America, USA, 22.2002) 